Review

\title{
Recent Progress on Hyperbranched Polymers Synthesized via Radical-Based Self-Condensing Vinyl Polymerization
}

\author{
Xiaofeng Wang and Haifeng Gao * \\ Department of Chemistry and Biochemistry, University of Notre Dame, Notre Dame, IN 46556, USA; \\ xwang26@nd.edu \\ * Correspondence: hgao@nd.edu; Tel.: +1-412-216-2895
}

Academic Editors: Chih-Feng Huang, Jinlian Hu and Rui Xiao

Received: 5 May 2017; Accepted: 18 May 2017; Published: 24 May 2017

\begin{abstract}
This short review article summarizes recent reports on using controlled radical polymerization (CRP) of inimers (compounds containing initiating group and vinyl group in one molecule) or transmers (compounds containing chain transfer group and vinyl group in one molecule) for the synthesis of hyperbranched polymers. These inimers and transmers that carry numerous functional groups could be homopolymerized, i.e., self-condensing vinyl polymerization, or copolymerized with monovinyl monomers, i.e., self-condensing vinyl copolymerization, using atom transfer radical polymerization (ATRP), nitroxide-mediated polymerization (NMP) or reversible addition fragmentation chain transfer (RAFT) polymerization techniques, producing hyperbranched polymers and hyperstar polymers with tunable molecular weights, compositions and degree of branching. Recent reports that attempted different strategies to regulate polymer-polymer reactions were introduced, demonstrating possible syntheses of hyperbranched polymers with better defined structures and relatively low molecular weight dispersity. Finally, several CRP-produced hyperbranched polymers were discussed on their applications for encapsulation of guest molecules, nanomedicine, diagnostic imaging and catalysis.
\end{abstract}

Keywords: hyperbranched polymer; controlled radical polymerization; inimer; transmer; self-condensing vinyl polymerization

\section{Introduction}

Highly branched polymers that are comprised of dendrimers and hyperbranched polymers represent an intriguing class of macromolecules with compact structure, high density of branching linkers, three-dimensional globular shape and multiple chain-end groups [1-6]. They have demonstrated promising properties for a variety of applications, ranging from specialty additives, lubricants and nanomedicine to molecular catalysis [7-10]. Interestingly, dendrimers and hyperbranched polymers present a sharp contrast regarding their structural controllability and synthetic simplicity. As compared to dendrimers that have an elegant structure at the cost of a sophisticated multi-step reaction $[2,11,12]$, hyperbranched polymers from the one-pot facile polymerization suffer random bimolecular reactions with no control of polymer structures $[1,3,8]$.

Till now, various techniques have been developed to synthesize hyperbranched polymers, including: (1) step-growth $[3,10]$ or chain-growth $[13,14]$ polymerization of $\mathrm{AB}_{m}(m \geq 2)$ monomers where $A$ and $B$ represent two functional groups that can react with each other; (2) step-growth copolymerization of $\mathrm{A}_{n}$ and $\mathrm{B}_{m}$ monomers ( $\left.m, n \geq 2, m \times n>4\right)$ [15-17]; (3) chain-growth polymerization of divinyl or multivinyl crosslinkers with or without monovinyl monomers [18-23]; (4) self-condensing ring-opening polymerization (SCROP) [24-26]; and (5) self-condensing vinyl polymerization (SCVP) [27]. In particular, the last method requires the use of controlled polymerization 
methods, such as controlled radical polymerization (CRP) [28-34], living ionic polymerization [35,36] and group transfer polymerization [37].

This review article highlights the recent progress on using CRP methods to produce hyperbranched polymers via routes of SCVP and self-condensing vinyl copolymerization (SCVCP) with monovinyl monomers. Three of the following sections focus on the use of nitroxide-mediated polymerization (NMP) [38-41] and atom transfer radical polymerization (ATRP) [42-68] of $A B^{*}$ inimers (compounds containing initiator fragment $\mathrm{B}^{*}$ and vinyl group $\mathrm{A}$ in one molecule) and reversible addition fragmentation chain transfer (RAFT) polymerization of transmers [69-103] (compounds containing chain-transfer group and vinyl group in one molecule) to produce various functional hyperbranched polymers. Photo-mediated radical polymerization of polymerizable "iniferter" monomers [71,104-107] is also discussed in the section of RAFT polymerization since iniferter monomers share very similar structures as transmers. In addition, recent progress on regulating the structural heterogeneity of hyperbranched polymers and on demonstrating functions of hyperbranched polymers in various applications are discussed in Sections 5 and 6, respectively. Meanwhile, hyperbranched polymers produced via SCVP using other initiation techniques, such as cationic polymerization [27,108], anionic polymerization [109-116], group transfer polymerization [37,117,118] and ruthenium-catalyzed coordinative polymerization [119], will not be discussed in this short review article.

\section{Synthesis of Hyperbranched Polymers Using NMP}

Immediately after the first report of NMP in 1993 by Georges [120], Hawker and Fréchet quickly applied the NMP method in the first synthesis of hyperbranched polymers (Figure 1) [38]. In this case, a styrenic $\mathrm{AB}^{*}$ inimer functionalized with an alkoxyamine initiating group was homopolymerized at $130{ }^{\circ} \mathrm{C}$ and produced a hyperbranched polymer in $72 \mathrm{~h}$ without gelation. The polymer showed an apparent molecular weight $M_{n}=6000$ based on linear polystyrene standards with a dispersity $M_{\mathrm{w}} / M_{\mathrm{n}}=1.40$ and a glass transition temperature $T_{\mathrm{g}}=45^{\circ} \mathrm{C}$. The produced hyperbranched polymer was further utilized as a macroinitiator (MI) for a second-step chain extension to produce a hyperbranched star (hyperstar) polymer with $M_{n}=300,000$ and $M_{w} / M_{n}=4.35$. Cleavage of the benzyl ether linkers in the hyperbranched polymers produced degraded products with lower molecular weights, confirming the presence and nature of branching units in the hyperstar polymers. This report also represents the first example on synthesis of hyperstar polymers using hyperbranched polymers as MIs.

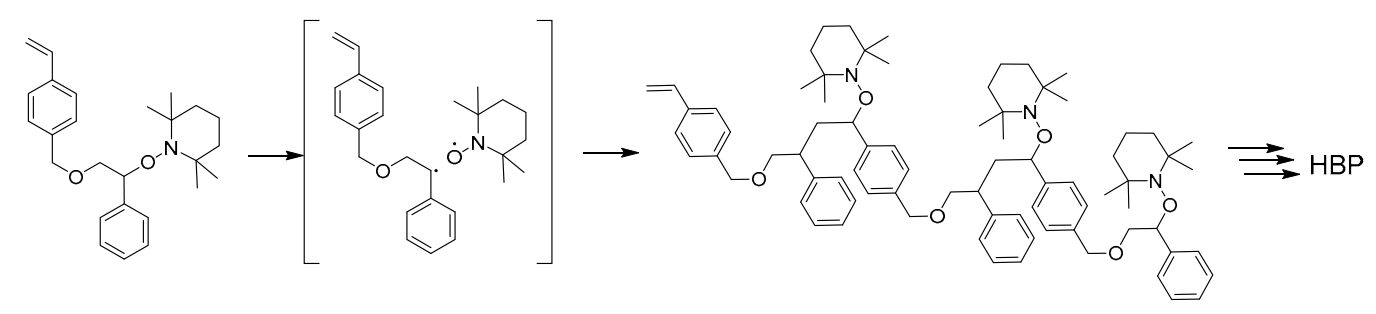

Figure 1. Illustration of the homopolymerization of an alkoxyamine-based inimer using nitroxide-mediated polymerization (NMP) self-condensing vinyl polymerization (SCVP) to form a hyperbranched polymer (HBP) [38].

Polymerizable nitroxides, such as 4-methacryloyloxy-2,2,6,6-tetramethyl-1-piperidinyloxy (MTEMPO) and 4-(4'-vinylphenylmethoxy)2,2,6,6-tetramethyl-1-piperidinyloxy (STEMPO) [40,72] (Figure 2), were used to introduce branching points into polymers. The branching points in these hyperbranched polymers underwent reversible thermolysis/recombination reactions at the C-nitroxide linkage, which mediates the polymerization and maintains the "livingness" of the polymers. 
<smiles>C=C(C)C(=O)OC1CC(C)(C)N(C)C(C)(C)C1</smiles>

MTEMPO

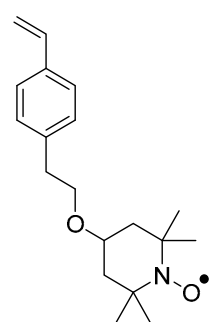

STEMPO

Figure 2. Structure of polymerizable nitroxides: 4-methacryloyloxy-2,2,6,6-tetramethyl-1-piperidinyloxy (MTEMPO) and 4-(4'-vinylphenylmethoxy)2,2,6,6-tetramethyl-1-piperidinyloxy (STEMPO).

Overall, NMP of inimers has been applied in a couple of very first reports for the preparation of hyperbranched polymers, although its broad application is limited by some challenges, including the slow polymerization kinetics, the often required high temperature, the inability to easily control methacrylate polymerization and the multi-step synthesis of alkoxyamine-based inimers [121]. In contrast, most of the hyperbranched polymers synthesized via CRP techniques were reported using either ATRP or RAFT methods, as will be discussed in the next two sections.

\section{Synthesis of Hyperbranched Polymers via ATRP}

The first ATRP SCVP of inimer was reported by Matyjaszewski using commercially available, $p$-(chloromethyl)styrene (CMS), in the presence of $\mathrm{Cu}(\mathrm{I})$ and 2,2'-bipyridine (bpy) [42] (Figure 3A). The structures of various $\mathrm{AB}^{*}$ inimers reported in the ATRP SCVP and ATRP SCVCP so far are listed in Table 1. Three types of inimers in terms of polymerizable vinyl group (A group) could be found in published reports covering: (1) acrylate inimers $\left(A B^{*} 1-9\right)$; (2) styrenyl inimers $\left(A B^{*} 10, A B^{*} 11\right)$; and (3) methacrylate inimers $\left(A B^{*} 12-20\right)$. The other ends of these $A B^{*}$ inimers all contained alkyl halide groups: either alkyl bromide or alkyl chloride, which generally employed Cu-based catalyst for initiating the polymerization.

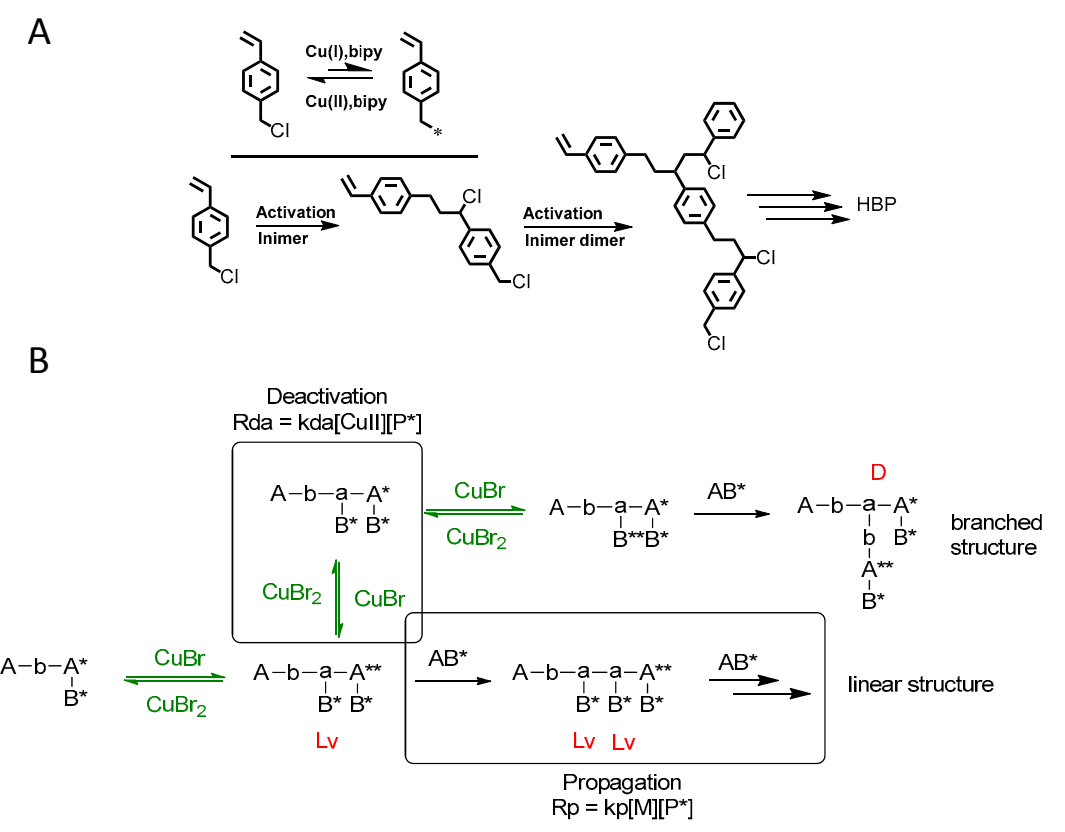

Figure 3. (A) Illustration of the homopolymerization of $p$-(chloromethyl)styrene (CMS) by atom transfer radical polymerization (ATRP) SCVP to form a hyperbranched polymer [42]; (B) Dynamic exchange during ATRP of inimer [47], $\mathrm{A}^{*}$ and $\mathrm{B}^{*}$ representing two types of dormant alkyl halogen initiating groups; $\mathrm{A}^{* *}$ and $\mathrm{B}^{* *}$ represent two types of propagating radicals. 
In general, the branched structure of hyperbranched polymers synthesized via ATRP of $\mathrm{AB}^{*}$ inimers is critically affected by the competition between radical propagation and deactivation reactions. Conceptually, a propagating radical from the activation of alkyl halide could either react with a new inimer to form a linear unit (such as $\mathrm{Lv}$ ) or be deactivated by reacting with $\mathrm{Cu}$ (II) deactivator (Figure 3B). An increased rate ratio of propagation over deactivation would produce more $\mathrm{Lv}$ linear units from one radical in an activation/deactivation cycle and lower the degree of branching (DB) of polymers. In contrast, a fast deactivation reaction could quickly stop the propagation of linear units and raise the chance of activating a different alkyl halide in another activation/deactivation cycle, which is the essential step to form a branched unit (D in Figure 3B) $[47,67,68,122]$.

It is useful to note that SCVP of inimers has both step-growth and chain-growth mechanistic features; high molecular weights and highly branched polymer structures could only be achieved at very high conversion. It was reported that SCVP of inimers $\mathrm{AB}^{*} 13$ and $\mathrm{AB}^{*} 14$ could not produce high molecular weight polymers using various ligands and temperatures mainly because of the fast radical termination reaction forming an excess amount of deactivator $\mathrm{Cu}$ (II) species. Thus, $\mathrm{Cu}$-based ATRP with the addition of $\mathrm{Cu}(0)$ for $\mathrm{AB}^{*} 13$ and $\mathrm{AB}^{*} 14$ [123] and Ni-based $\mathrm{CRP}$ for $\mathrm{AB}^{*} 13$ [52] were applied to achieve better results. The accumulated deactivator $\mathrm{Cu}(\mathrm{II})$ during ATRP of inimers could also be removed using a heterogeneous microemulsion polymerization system. For instance, the polymerization of inimer $\mathrm{AB}^{*} 13$ in a microemulsion not only regulated the polymer structure based on the dimension and uniformity of the discrete latexes, but also significantly increased the polymerization kinetics via the effective partition of $\mathrm{Cu}$ (II) deactivator into aqueous media [45,47].

So far, a few reports have been published on ATRP SCVP of styrenic $A B^{*}$ inimers. AB*10 and $A B^{*} 11$ as shown in Table 1 are two representative examples, in which the asymmetric structure of $A B^{*} 10$ offered tunable structures from linear to hyperbranched under different temperatures and ligands [65]. Through manipulating three polymerization parameters including temperature, ligand and solvents, the authors could manipulate the reactivities of initiating groups and catalysts and the solubility of deactivators in the polymerization solution, resulting in polymers with different architectures $[67,68]$. Low reaction temperature with high concentration of $\mathrm{Cu}$ (II) deactivator gave a higher chance of activation from the formed $\mathrm{A}^{*}$ initiating site, forming linear polyester LP1. In contrast, the use of less reactive and low-concentration deactivator promoted the polymerization from $\mathrm{B}^{*}$ sites and produced linear polymer LP2 (Figure 4). Between these two situations, a series of branched polymers with different $\mathrm{DB}$ values could be produced by simply tuning the reaction temperature and the effective concentration of deactivators in solution. The linear polymers LP1 and LP2 that carried many reactive benzylic bromides on the backbone have further potentials for modification via organic and polymerization reactions to incorporate additional functionalities on the polymers.

Table 1. Summary of $\mathrm{AB}^{*}$ inimers used in ATRP SCVP.

$\mathrm{AB}^{*}$ Reference Structure


Table 1. Cont.

AB* Reference Structure

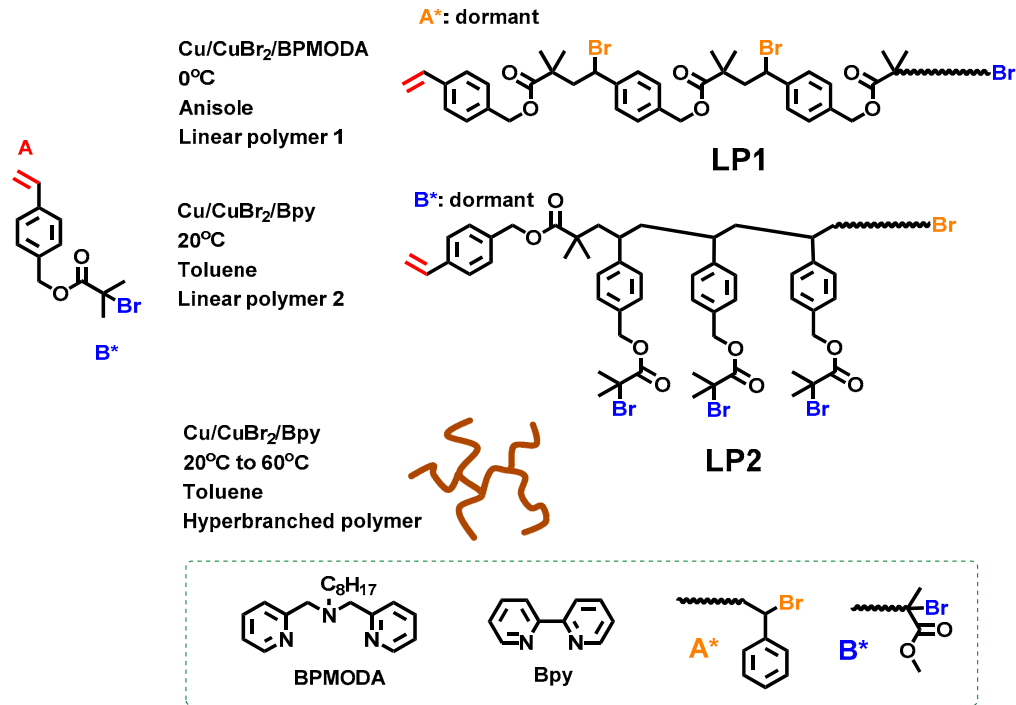

Figure 4. Control of polymer architectures in the ATRP SCVP of AB*10. Reproduced with permission [65], copyright 2010 American Chemical Society

\section{Synthesis of Hyperbranched Polymers by RAFT}

Chain transfer agent (CTA), usually a thiocarbonylthio compound with a structure as $Z(C=S) S R$, is the key component in the RAFT process, which mediates the equilibrium between active and dormant chains. The Z-group activates the thiocarbonyl double bond and provides stability to the intermediate adduct formed when radicals are added to the CTA, while the R-group is a good leaving group capable of reinitiating RAFT polymerization after fragmentation. Similar as an $\mathrm{AB}^{*}$ inimer in ATRP and NMP, 
the monomer used in RAFT SCVP composes a polymerizable vinyl group (A group) installed into the CTA structure (equivalent to the $\mathrm{B}^{*}$ group) on either the R-group or Z-group side. Different from the $\mathrm{AB}^{*}$ inimer that has a real initiating group $\mathrm{B}^{*}$, the polymerizable CTA used in the RAFT method needs an external radical source to cleave the $\mathrm{S}-\mathrm{R}$ bond and generate a propagating radical. This structural difference gives the polymerizable CTA another name, i.e., transmer. Although designing a transmer by placing a polymerizable vinyl group at either the $R$ group ( $R$ approach) or the $Z$ group ( $Z$ approach) is available, two main limitations of the Z-approach become significant: steric hindrance to access the CTA functionalities and the potential weakness of the branch points (Figure 5) [71,128]. To solve this problem, Puskas and coworkers reported the first bulk polymerization of styrene with 4-vinylbenzyl dithiobenzoate, which avoided introducing the CTA into the branching point (R method; Figure 5A) [78]. Till now, the R method was utilized more frequently to produce a variety of branched polymer structures. Table 2 summarizes the transmers that have been prepared and reported to date. While the first transmer reported was strictly limited to styrenic polymerizable group, new examples of transmers with acrylate/methacrylate polymerizable groups were developed [77]. Xanthate-based transmers reported by both Poly's [81] and Zhou's [83] groups were subsequently used to prepare hyperbranched poly(vinyl acetate). The development of these new transmers was crucial for this vinyl ester monomer because poor control was always achieved using any other CTAs. The most commonly reported iniferter monomers contain dithiocarbamate (DC) chain-transfer group. Photopolymerizations in benzene solution of 2-(N,N-diethylaminodithiocarbamoyl)ethyl methacrylate (DTCM, Entry 21 Table 2) were carried out by Mori et al. [106] via irradiation with UV light in a sealed glass ampoule under high vacuum at $20^{\circ} \mathrm{C}$.

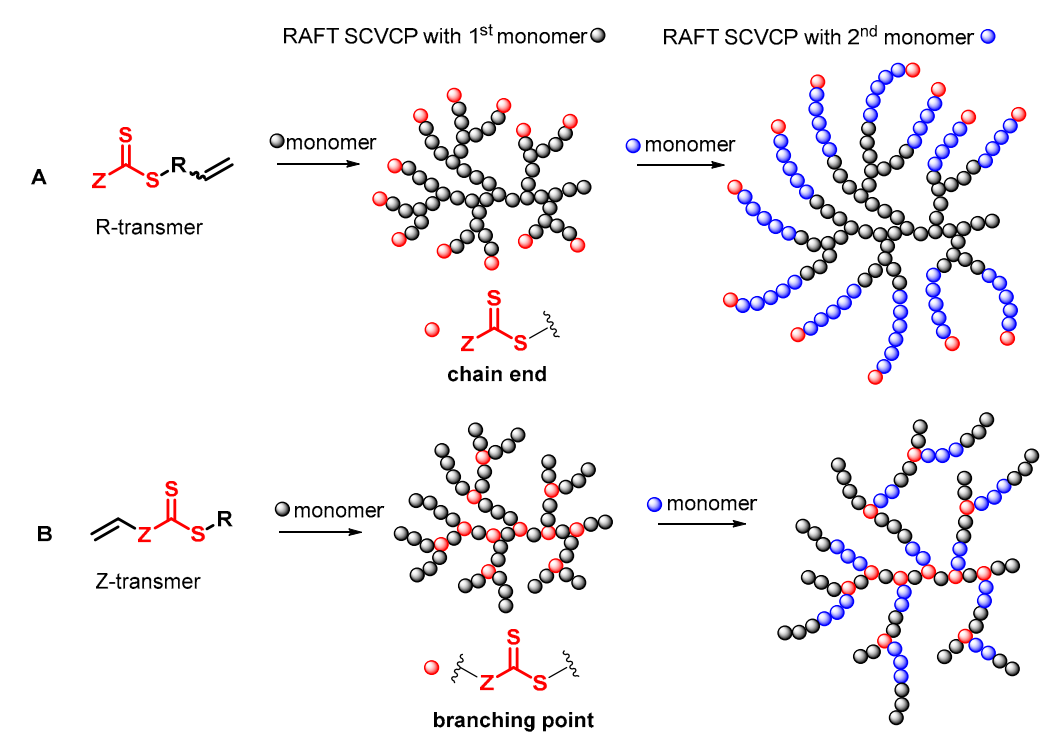

Figure 5. General structures of transmers for (A) R method and (B) $\mathrm{Z}$ method to produce hyperbranched polymers.

In the RAFT polymerization of transmers, so far, only a handful of examples have reported the homopolymerization of transmers. In 2011, Zhao and coworkers [82] used S-(4-vinyl)benzyl $S^{\prime}$-propyl trithiocarbonate (VBPT) to prepare a hyperbranched polymer as a control experiment with the intention to compare the solution behavior of branched copolymers obtained by RAFT SCVCP. A thorough literature research to the best of our knowledge indicates that RAFT homopolymerization of transmers when using thermal initiators as radical sources could only produce low molecular weight hyperbranched polymers. The highest molecular weights available in several reports include $M_{\mathrm{n}}=24,700$ in Zhao's group [82], $M_{\mathrm{n}}=8740$ in Sumerlin's group [80] and $M_{\mathrm{n}}<1000$ in Poly's group [81]. On the other hand, Ishizu and Tanaka reported the photo-polymerization of iniferter 
monomers and produced hyperbranched polymers with molecular weight above 100,000 [129,130]. Recently, our group reported a systematic study of the homopolymerization of a trithiocarbonate transmer and produced the first hyperbranched polymers with over half-a-million molecular weight by applying a concurrent ATRP/RAFT initiation process that generated radicals without the use of thermal initiator [131].

Most of the RAFT polymerizations of transmers were conducted by SCVCP with various functional monovinyl monomers, which makes it easy to tune the DB and introduce reactive groups in the segmented hyperbranched polymers (SHBPs). The addition of monovinyl monomers diluted the branching density and consequently lowered the DB in general. To achieve a uniform distribution of branching units in the copolymer structure, similar reactivity between the polymerizable group of the transmer and the vinyl group of the comonomer is critical. The first report of the RAFT SCVCP was published in 2003 by Yang et al., who utilized RAFT SCVCP to prepare hyperbranched polystyrene [72]. The transmer structure was based on a styrenic dithioester transmer 1 (Table 2) with a styrenyl unit as the Z-group. By introducing the dithioester group into the branching point, it offers an advantage to prepare segmented hyperbranched copolymers through a two-step polymerization method. As shown in Figure 5B, one monovinyl monomer was copolymerized with transmer first to produce a hyperbranched macro-transfer agent before the polymerization of a second monomer by inserting the second block at the reactive CTA branching points, generating branched block-copolymers. In contrast, star-shaped copolymers would be produced if the hyperbranched polymers were made out of the R method since the CTA groups are at the periphery of the hyperbranched polymers (Figure 5A). This was utilized by Patrickios and coworkers to produce segmented amphiphilic hyperbranched polymers of styrene and vinylpyridine through stepwise RAFT SCVP [97]. In comparison to NMP SCVP and ATRP SCVP, which could only provide star-shaped copolymers, RAFT SCVP and RAFT SCVCP offer more options to alter the polymer structures by using different transmer structures.

Table 2. Summary of transmers used in RAFT SCVP.

Transmer
[72,78,86,97]


Table 2. Cont.

\begin{tabular}{|c|c|c|c|c|}
\hline Transmer & Structure & Vinyl Group $^{a}$ & CT Group $^{b}$ & Reference \\
\hline 9 & & A & TTC & {$[84,92,101]$} \\
\hline 10 & & A & TTC & [85] \\
\hline 12 & & A & TTC & [88] \\
\hline 13 & & A & TTC & {$[77,80]$} \\
\hline 14 & & M & TTC & [98] \\
\hline 15 & & M & TTC & [94] \\
\hline 16 & & M & TTC & {$[87,92]$} \\
\hline 17 & & S & TTC & [95] \\
\hline 18 & & S & TTC & {$[82,93]$} \\
\hline 19 & & S & TTC & {$[89,90]$} \\
\hline 20 & & M & TTC & [99] \\
\hline 21 & & S & Carbamate/iniferter & [129] \\
\hline 22 & & M & Carbamate/iniferter & [106] \\
\hline 23 & & M & Thiol & [132] \\
\hline
\end{tabular}

${ }^{a}$ Vinyl groups include: S: styrenyl; A: acrylate; M: methacrylate; VA: vinyl acetate; ${ }^{\text {b }}$ chain transfer (CT) groups include: DTB: dithiobenzoate; TTC: trithiocarbonate; DTC: xanthate (dithiocarbonate); TTC: trithiocarbonate.

\section{Attempts to Regulate the Structures of Hyperbranched Polymers}

Most of the reported hyperbranched polymers were synthesized by radical polymerization in bulk or solution. The homogeneous reaction media cause random monomer-monomer, monomer-polymer and polymer-polymer reactions throughout the reactor, which leads to polymers with poorly defined structure, i.e., high dispersity. Since the physical properties of hyperbranched polymers are critically influenced by their molecular weights and structural uniformity, it is highly desirable to develop robust synthetic methods that can regulate the molecular weight distribution (MWD) of hyperbranched polymers with minimal compromise of the facile one-pot synthesis feature. So far, two major methods 
were applied to provide a better control over the dispersity of hyperbranched polymers. The first method is the application of a multifunctional core molecule via either slow addition of monomers into a dilute solution of the multifunctional core or the use of core molecule carrying more reactive groups than those on monomers. The main concept is to achieve a desired chain-growth polymerization via selective monomer-polymer reactions and disfavor monomer-monomer reactions. In contrast, the second method focuses on segregating the polymerization of monomers in a confined nanospace in order to decrease the dispersity of hyperbranched polymers.

According to the simulation reported by Frey et al. [133] and Müller et al. [134], the slow addition of $\mathrm{AB}_{m}$ monomers or $\mathrm{AB}^{*}$ inimers into a solution of the multifunctional $\mathrm{B}_{x}(x \geq 2)$ core could decrease the dispersity and increase the DB value of the hyperbranched polymers. In a situation when $\mathrm{AB}_{m}$ monomers only react with the $\mathrm{B}$ functional groups on the $\mathrm{B}_{x}$ core, at complete conversion, hyperbranched polymers with $M_{\mathrm{W}} / M_{\mathrm{n}}=1+(m-1) / x$ are produced. Based on this theory, many research groups applied a variety of $\mathrm{AB}_{m}+\mathrm{B}_{x}$ pairs and achieved experimental results qualitatively supporting the simulation. However, examples of radical polymerization using $\mathrm{AB}^{*}$ inimer and $\mathrm{B}_{x}{ }^{*}$ core are rare. Pan et al. applied a tetrafunctional initiator core (Core 1, Figure 6 ) in the ATRP SCVP of inimer $\left(\mathrm{AB}^{*} 15\right.$, Table 1$)$ and produced hyperbranched polymers with the most uniform structure $\left(M_{\mathrm{W}} / M_{\mathrm{n}}=2.16\right)$ with a molar ratio of $\left[\mathrm{AB}^{*} 15\right]_{0} /[\text { core } 1]_{0}=28$ [51]. In order to obtain hyperbranched polymers with even lower dispersity (e.g., $M_{\mathrm{w}} / M_{\mathrm{n}}=1.5$ ), the initial feed ratio of inimer to core was limited to less than 100:1, and the polymerization required slow monomer addition during the polymerization. Different from using the slow monomer addition strategy to favor the monomer-polymer reaction, increasing the reactivity of the core molecules with respect to monomers could also decrease the dispersity of the resulting polymers. The strategy of using a high-reactivity core (Core 2, Figure 6) was applied in the ATRP SCVP of inimers AB*8 (Table 1) to synthesize hyperbranched polymers with low dispersity [50]. Within the studies, an optimal feed ratio of $\left[\mathrm{AB}^{*} 8\right]_{0} /[\text { Core } 2]_{0}=40: 1$ in one pot produced polymers with $M_{\mathrm{W}} / M_{\mathrm{n}}<1.5$.

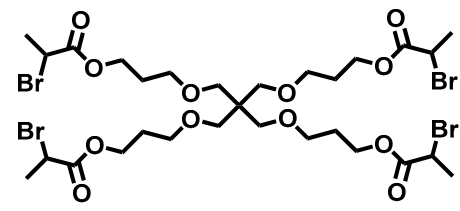

core 1

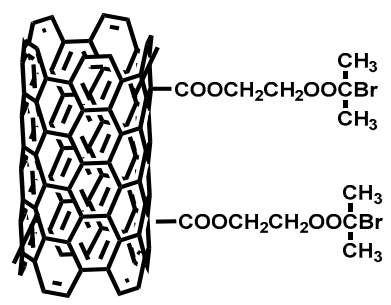

core 3

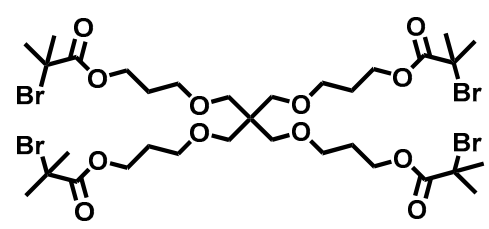

core 2

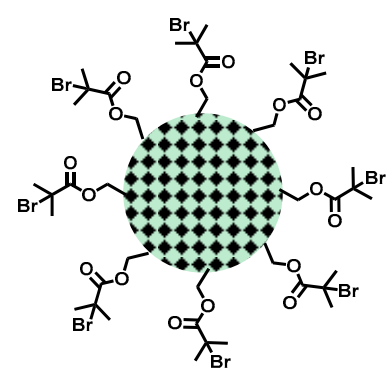

core 4

Figure 6. Structure of multifunctional cores reported in recent publications to produce hyperbranched polymers with a narrow molecular weight distribution (MWD).

As an alternative method, the growth of hyperbranched polymers from an insoluble support could also lower the polymer dispersity. Moore et al. applied a multifunctional ATRP initiator based on surface-functionalized multi-walled carbon nanotubes (Core 3, Figure 6) for the polymerization of $\mathrm{AB}^{*} 8$ (Table 1) [135]. The resulting nanotubes with a hyperbranched polymer shell showed good dispersibility in THF and $\mathrm{CHCl}_{3}$, although no $\mathrm{DB}$ and dispersity values were determined. A second 
example synthesized hyperbranched polymers grafted on the exterior surface of mesoporous silica nanoparticles (MSN, Core 4, Figure 6) by surface-initiated ATRP of AB*8 (Table 1) [59]. It was found that the molecular weights of hyperbranched polymers after cleavage from the MSN core increased from $M_{n}=18.6 \times 10^{3}-29.2 \times 10^{3}$ when the initial weight ratios of $\left[\mathrm{AB}^{*} 8\right]_{0} /[\text { Core } 4]_{0}$ changed from $30-125$ with relatively low dispersity $\left(M_{\mathrm{w}} / M_{\mathrm{n}}=1.80-2.30\right)$.

In contrast to the homogeneous solution polymerization, our group recently reported the application of heterogeneous micelle-based confined space, i.e., microemulsion, to regulate the synthesis of hyperbranched polymers by conducting one-pot ATRP SCVP of AB* inimers (Figure 7) [45]. The random polymer-polymer reactions were effectively confined in each discrete polymerizing nanoparticle in the microemulsion, and the obtained hyperbranched polymers showed narrow MWD and a hydrodynamic size similar to that of nanoparticles, i.e., one hyperbranched polymer per latex particle by the end of the polymerization. This ATRP of inimers in heterogeneous microemulsion has been demonstrated as a robust method by exploring five methacrylate-based inimers under various microemulsion conditions [47]. The produced hyperbranched polymers showed varied compositions with tunable $\mathrm{DB}=0.26-0.41$, molecular weights $\left(M_{\mathrm{n}}=194 \times 10^{3}-1301 \times 10^{3}\right)$ and low dispersity $\left(M_{\mathrm{w}} / M_{\mathrm{n}}=1.1-1.7\right)$.

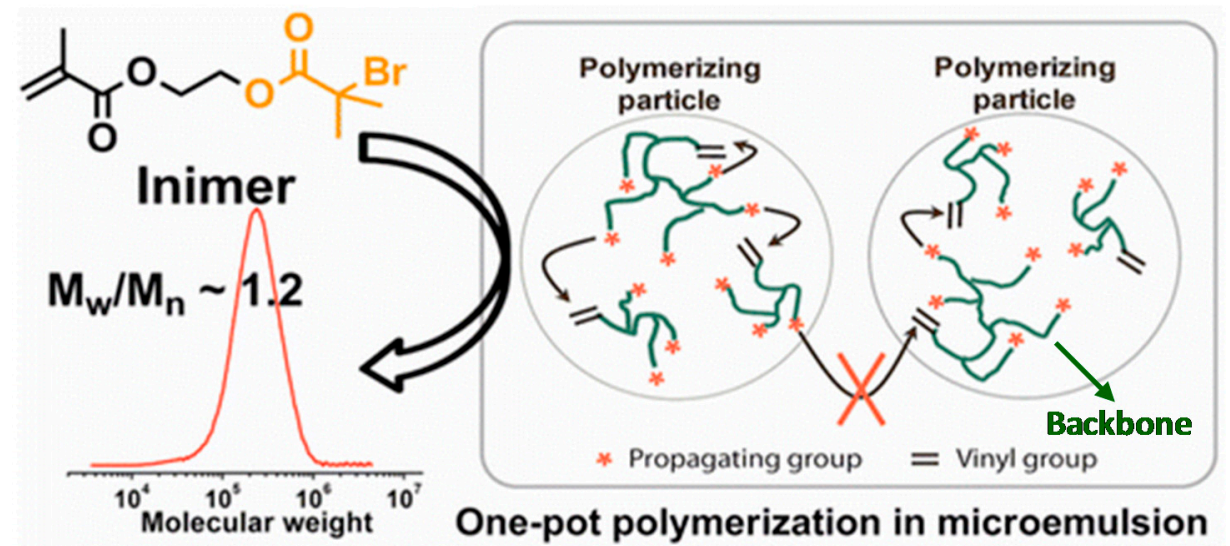

Figure 7. Polymerization of inimers in microemulsion. Reproduced with permission [45], copyright 2012 American Chemical Society.

Meanwhile, all hyperbranched polymers produced within the spatially-confined micelles (i.e., latexes) contained hundreds of bromine initiating sites. They could be subsequently used as MIs for polymerization of another functional monomer to synthesize hyperstar polymers with core-shell structures. The composition and dimension of the core and shell segments could be independently controlled based on several experimental variables, including the monomer species, the feed ratios and the conversions. Very recently, this type of synthesis was further accomplished in a one-pot procedure via sequential polymerization of $\mathrm{AB}_{m}$ monomer and a second functional monomer in the oil-in-water emulsion. The surfactant-protected emulsion latexes functioned as segregated reactors to effectively eliminate the undesired star-star coupling, achieving both high monomer conversion and fast polymerization at the same time [48]. We anticipate that the general concept of polymerization in confined space will enable many synthetic opportunities to better regulate the side reactions and produce various structurally-defined polymer nanostructures, including star polymers, cyclic polymers and graft polymers. In addition, Jiang's group conducted a radical copolymerization of styrene with Transmer 23 (Table 2) (3-mercaptohexyl methacrylate) in an aqueous emulsion system with high monomer/transmer ratio (100/25), producing branched polymers with $M_{\mathrm{W}} / M_{\mathrm{n}}=5.37$ [132]. As compared to the previous microemulsion system, this emulsion polymerization seems less effective in controlling the polymer structure, probably due to the poor uniformity of the emulsion latexes and the presence of many branched polymers per latex particle. 


\section{Applications of Hyperbranched Polymers Produced from Radical-Based SCVP}

In general, hyperbranched polymers display many useful properties, such as highly compact structure, few chain entanglements, high solubility, low viscosity and multiple peripheral groups. They have been utilized in various fields ranging from photoelectric materials, nanotechnology, biomedicines, composites, coatings, adhesives and lubricants. Regarding the hyperbranched polymers produced from controlled radical SCVP, a few examples have been published recently giving emphasis on the functionality.

\subsection{Hyperbranched Polymers for Loading Guest Molecules}

Hyperbranched polymers are considered as unimolecular containers and could be applied as hosts to encapsulate small guest molecules. The loading capability of hyperbranched polymers is one of the most important parameters, which is critically affected by the density and functionality of the branching points. For instance, as compared to commonly-used nanogels that have an " "-shaped branching unit from which four chains radiate out, hyperbranched polymers have a " $\mathrm{T}$ "-shaped branching unit from which three arms radiate out (Figure 8). The effect of branching unit structure on the loading properties of these two unimolecular containers was first studied by our group. A family of hyperbranched polymers and crosslinked nanogels with similar molecular weights, similar hydrodynamic diameters in THF and the same density of azido groups per structural unit were synthesized via ATRP and conventional radical polymerization (RP) of azido-functionalized inimers, divinyl cross-linkers and monovinyl monomers in microemulsion. The hyperbranched polymers demonstrated three-times higher loading efficiency than crosslinked nanogels when both reacted with three alkynyl-containing dendron molecules using Cu-catalyzed azide-alkyne cycloaddition (CuAAC) reactions (Figure 8) [49].

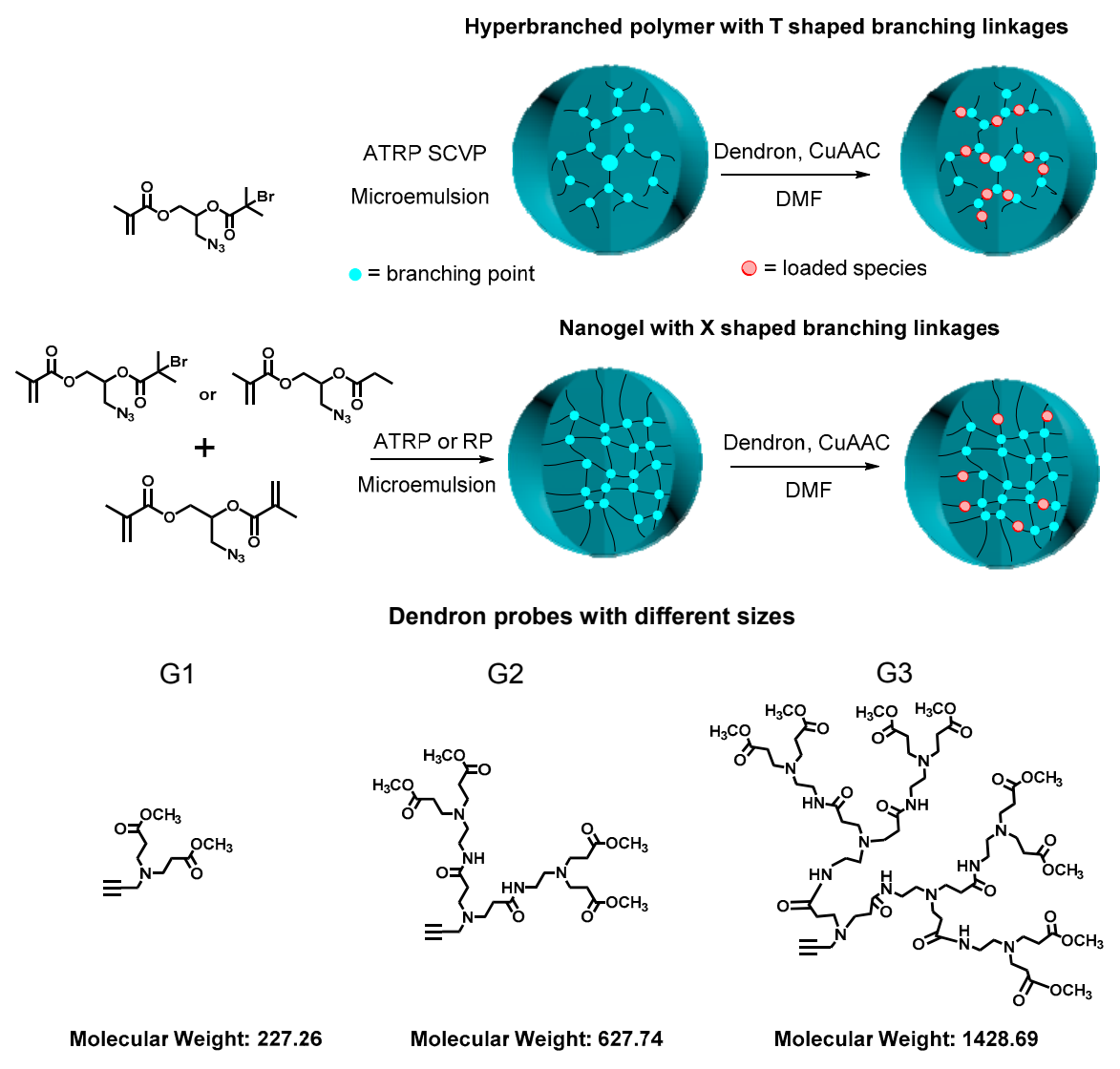

Figure 8. Structures of hyperbranched polymers and crosslinked nanogels and their influence on loading efficiency of Dendron molecules. Reproduced with permission [49], copyright 2015 John Wiley and Sons. 
In a separate study, the Gao Chao group at Zhejiang University reported that the high polarity difference between the core and shell of an amphiphilic hyperbranched polymer could selectively load organic dyes into the core domain [92]. In this study, core-shell amphiphilic hyperbranched polymers were produced by RAFT SCVCP of Transmer 9 (Table 2) and 2-(dimethylamino)ethyl methacrylate (DMAEMA) monomer in one pot. After chain extension with polystyrene to introduce the hydrophobic shell, the multifunctional tertiary amino groups in the core were converted into quaternary ammonium by reacting with propargyl bromide, which can efficiently load azido-functionalized dye molecules into the charged hydrophilic core area in high efficiency.

\subsection{Application of Hyperbranched Polymers for Drug Delivery}

Hyperbranched polymers have potential applications in nanomedicine because of their compact architecture and multiple peripheral chain ends, enhancing multivalent targeting efficiency. In 2015, Pan's and Gao's groups reported the ability of a novel combinatorial therapy targeting triple negative breast cancer cells using a hyperstar polymer (HSP) to encapsulate two enzyme inhibitors inside: niclosamide (e.g., 5-chloro- $N$-(2-chloro-4-nitrophenyl)-2-hydroxybenzamide), a known STAT3 inhibitor and amonafide (e.g., 5-amino-2-[2-(dimethylamino)ethyl]-1H-benzo[de]isoquinoline-1,3(2H)-dione), an agent activating topoisomerase-II pathways [136]. The HSP was constructed in two steps: ATRP of $\mathrm{AB}^{*} 19$ inimer (Table 1 ) in microemulsion followed by a surface-initiated ATRP of DMAEMA in solution (Figure 9). After encapsulation of given amounts of inhibitors, this nano-cocktail showed at least $2-4$-fold better inhibition of triple negative breast cancer cells than the individual drugs and 6-20-times more selective than the parent drugs.

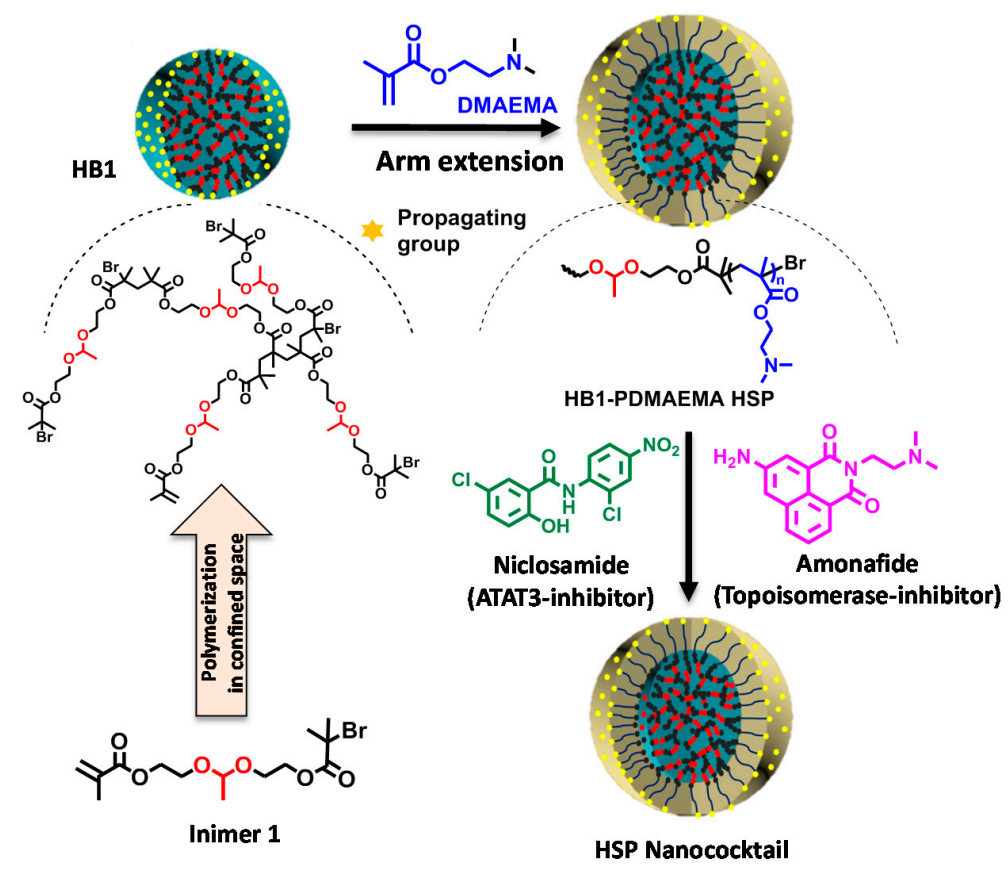

Figure 9. Hyperbranched macroinitiators (MIs) for the synthesis of degradable hyperstar polymers (HSPs) in water. Reproduced with permission [136], copyright 2015 Royal Society of Chemistry. DMAEMA, 2-(dimethylamino)ethyl methacrylate.

Gong et al. reported an enzyme- and $\mathrm{pH}$-sensitive branched poly[N-(2-hydroxypropyl) methacrylamide] (polyHPMA) copolymer-doxorubicin conjugate, which was prepared via a one-pot RAFT SCVCP of one transmer and three functional monomers followed by drug conjugation (Figure 10) [137]. The amphiphilic polymer-drug conjugates formed nanoparticles in water, but degraded to low molecular weight products in the presence of papain or cathepsin B. The drug-conjugated polymer 
nanoparticles exhibited greater accumulation in breast tumors and released doxorubicin molecules under acidic environment, resulting in enhanced antitumor therapeutic indexes with targeted delivery.

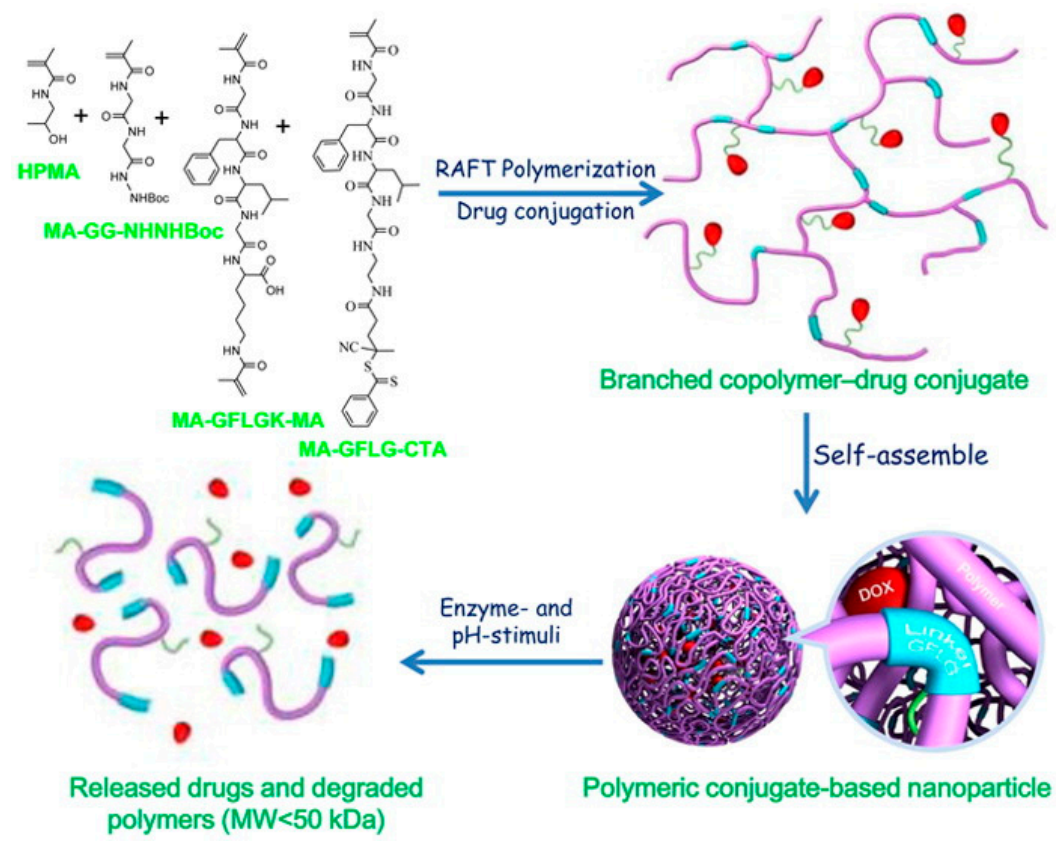

Figure 10. Schematic representation of the synthesis, assembly and degradation of poly[N-(2-hydroxypropyl) methacrylamide] (polyHPMA) copolymer. Reproduced with permission [137], copyright 2016 American Chemical Society.

In another report, $\mathrm{Lu}$ and coworkers prepared a redox-responsive branched polymer-drug conjugate, in which the branched poly(VBPT-co-PEGMA) was synthesized by one-pot RAFT copolymerization of $S$-(4-vinyl) benzyl $S^{\prime}$-propyl trithiocarbonate (VBPT) transmer and poly(ethylene glycol) methacrylate (PEGMA) monomer followed by several steps of chain-end transformations (Figure 11) [93]. The amphiphilic polymer-drug conjugates self-assembled into micelles in aqueous solution and destructed under the reductive cellular environment to release the anticancer drug 6-mercaptopurine.

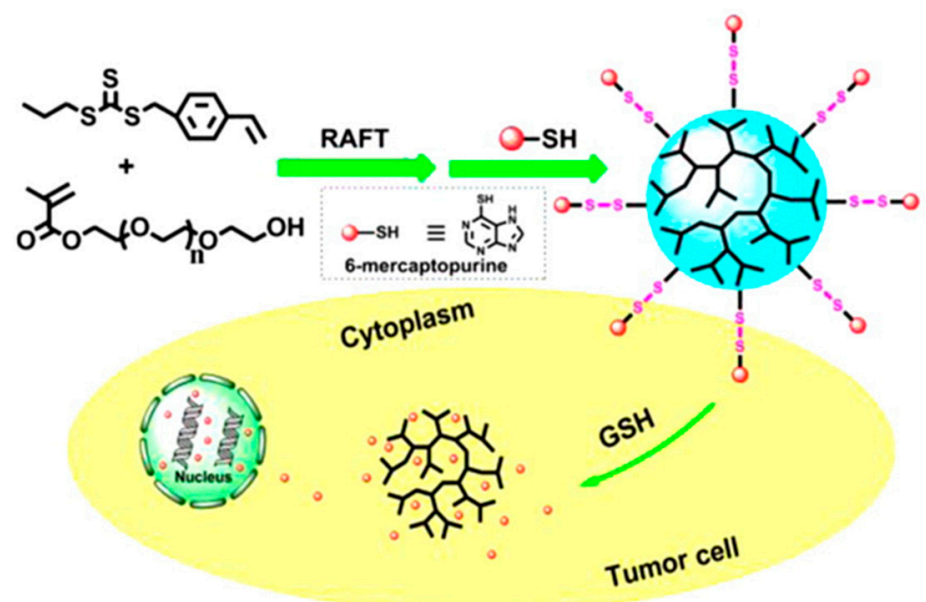

Figure 11. Redox-responsive branched polymer-drug conjugate with branched poly(S'-propyl trithiocarbonate (VBPT)-co-PEGMA). Reproduced with permission [93], copyright 2014 American Chemical Society. 


\subsection{Application of Hyperbranched Polymers for Bioimaging}

There is great interest in developing active targeting nanomaterials for various diagnostic bioimaging applications, such as magnetic resonance imaging (MRI), to alter biodistribution and improve imaging sensitivity [138]. Robins et al. used RAFT SCVP and synthesized branched block copolymers carrying 1,4,7,10-tetraazacyclododecane- $N, N^{\prime}, N^{\prime \prime}, N^{\prime \prime \prime}$-tetraacetic acid (DO3A) macrocycles within their cores and octreotide (somatostatin mimic) cyclic peptides at their periphery (Figure 12A) [139]. These polymeric nanoparticles have been chelated with $\mathrm{Gd}^{3+}$ and applied as MRI nanocontrast agents. As another example of the application of hyperbranched polymer in MRI, Whittaker et al. produced a series of highly branched polymers consisting of fluoro- and PEG-based segments by RAFT SCVCP (Figure 12B) [98]. It was demonstrated that the chain sequence of fluorinated monomers along the polymer backbone and the polymer DB values significantly determined the final ${ }^{19} \mathrm{~F}$ NMR properties.

\section{A}

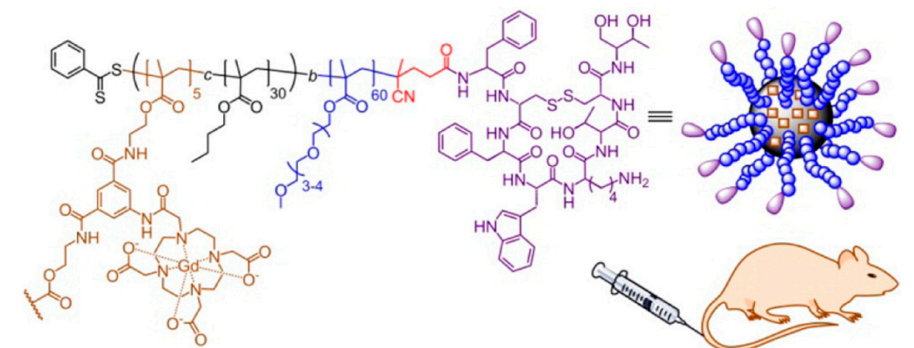

B

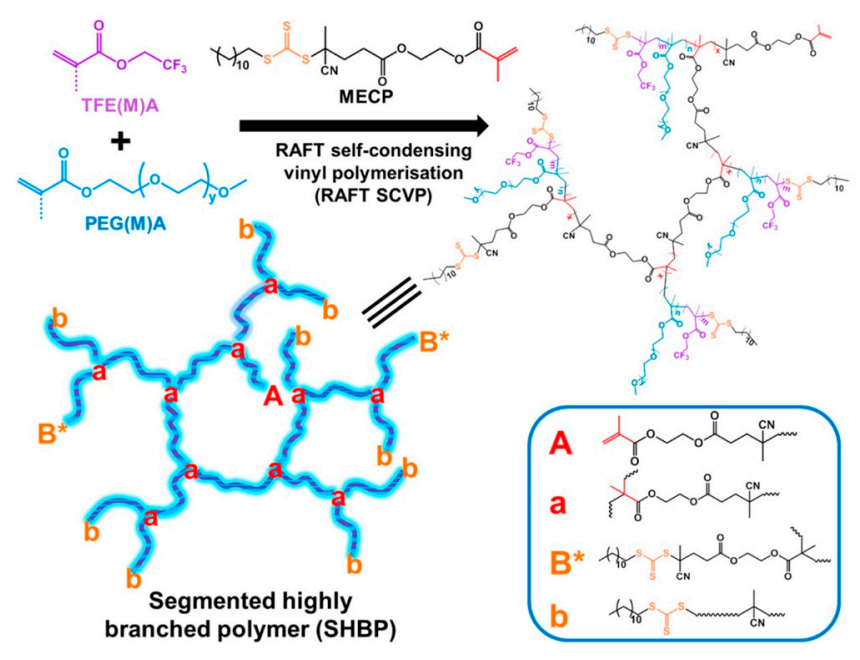

Figure 12. (A) Octreotide-functionalized contrast agent for targeted MRI; (B) illustration of the synthesis of segmented hyperbranched polymers via RAFT SCVP. Reproduced with permission [98,139], copyright 2015 and 2016 American Chemical Society.

\subsection{Application of Hyperbranched Polymers for Catalysis}

Hyperbranched polymers synthesized via CRP methods have also been used as unimolecular containers to stabilize catalytic metal nanoparticles inside. Recently, our group developed a type of reusable hyperstar polymer- $\mathrm{Au}_{25}(\mathrm{SR})_{18}$ nanocomposites for catalysis of reduction of 4-nitrophenol by $\mathrm{NaBH}_{4}$ [140]. A hyperbranched copolymer was first constructed via ATRP SCVCP of AB*13 inimer (shown as BIEM in Figure 13) with a cyclic disulfide-containing methacrylate monomer (MAOELP) in microemulsion in a 5:1 molar feed ratio, before it was used as an MI for polymerization of oligo(ethylene glycol) methyl ether methacrylate (OEGMA, $M_{n}=500$ ) to grow the radiating arms. The hyperstar polymer HS-(MAOELP $\left.{ }_{1}-\mathrm{r}-\mathrm{BIEM}_{5}\right) @ \mathrm{POEGMA}$ with disulfide groups was proven to efficiently encapsulate $\mathrm{Au}_{25}(\mathrm{SR})_{18}$ nanoclusters through ligand exchange without destroying the fine 
structure of the $\mathrm{Au}_{25}(\mathrm{SR})_{18}$ clusters. The obtained hyperstar- $\mathrm{Au}_{25}(\mathrm{SR})_{18}$ nanocomposites showed great stability with no size change after a three-month shelf storage. They were used as efficient catalysts for the catalytic reduction of 4-nitrophenol by $\mathrm{NaBH}_{4}$ in five cycles, showing convenient catalyst recovery without losing catalytic efficiency.

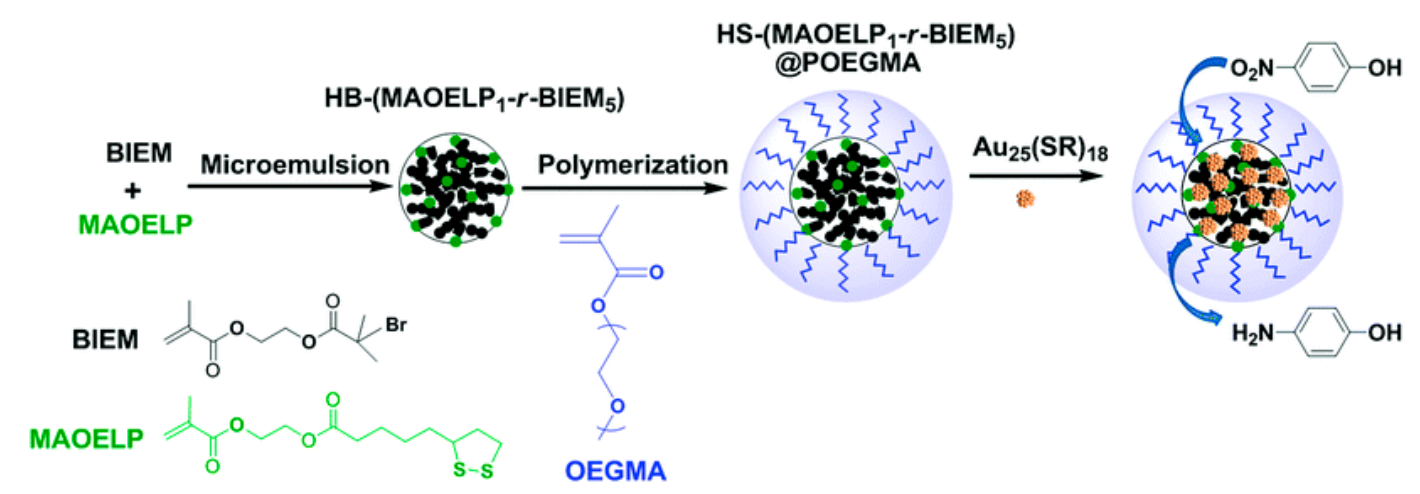

Figure 13. Preparation of HS-(MAOELP $\mathrm{M}_{1}$-r-BIEM $)$ @POEGMA stabilized $\mathrm{Au}_{25}(\mathrm{SR})_{18}$ for catalytic reduction of 4-nitrophenol. Reproduced with permission [140], copyright 2017 Royal Society of Chemistry. OEGMA, oligo(ethylene glycol) methyl ether methacrylate.

\section{Conclusions and Outlook}

Here, we summarize the recent progress on using CRP methods, including NMP, ATRP and RAFT, to produce hyperbranched polymers and their exploration as materials in numerous applications. By copolymerizing inimers or transmers with monovinyl monomers, the SCVP technique could be extended to SCVCP that allows easy functionalization of the hyperbranched copolymers with various reactive groups and tunable DB values. Currently, most of the hyperbranched polymers synthesized by using this method suffered from limited structural control, i.e., the broad molecular weight distribution, due to the random polymer-polymer reaction. Several methods have been explored to better control the polymer structures, such as the application of a multifunctional core and the use of a confined space. Robust synthetic methods are still in high demand that can achieve accurate placement of one or a few monomers per time into a hyperbranched polymer with the orthogonality of reactive groups for the modification in different domains. In particular, photo-mediated CRP methods [141,142], any ATRP techniques with ppm amount of $\mathrm{Cu}[143]$ or no $\mathrm{Cu}$ catalysts $[144,145]$ are expected to be applied in the polymerization of inimers and transmers for producing hyperbranched polymers with robust conditions, free of catalyst contaminants and better control of polymer structures [146]. Meanwhile, the intriguing features of these hyperbranched polymers for easy synthesis and multiple chain-end groups have attracted the exploration of their applications as materials in drug delivery, imaging diagnostics and catalysis. These progresses establish a more comprehensive structure-property relationship about these CRP-produced hyperbranched polymers for their broad utilization in industrial applications.

Acknowledgments: The authors thank the ARO YIP award (W911NF-14-1-0227), the University of Notre Dame, the Center for Sustainable Energy at Notre Dame and the NDnano for financial support.

Author Contributions: Xiaofeng Wang surveyed the literature, wrote the manuscript, and designed the presentation of some figures. Haifeng Gao revised the manuscript and overviewed the structure of this review article.

Conflicts of Interest: The authors declare no conflict of interest.

\section{References}

1. Kim, Y.H. Hyperbranchecs polymers 10 years after. J. Polym. Sci. A 1998, 36, 1685-1698. [CrossRef]

2. Grayson, S.M.; Fréchet, J.M.J. Convergent dendrons and dendrimers: From synthesis to applications. Chem. Rev. 2001, 101, 3819-3867. [CrossRef] [PubMed] 
3. Gao, C.; Yan, D. Hyperbranched polymers: From synthesis to applications. Prog. Polym. Sci. 2004, 29, 183-275. [CrossRef]

4. Schoemer, M.; Schuell, C.; Frey, H. Hyperbranched aliphatic polyether polyols. J. Polym. Sci. A 2013, 51, 995-1019. [CrossRef]

5. Zheng, Y.; Li, S.; Weng, Z.; Gao, C. Hyperbranched polymers: Advances from synthesis to applications. Chem. Soc. Rev. 2015, 44, 4091-4130. [CrossRef] [PubMed]

6. Kurniasih, I.N.; Keilitz, J.; Haag, R. Dendritic nanocarriers based on hyperbranched polymers. Chem. Soc. Rev. 2015, 44, 4145-4164. [CrossRef] [PubMed]

7. Frechet, J.M.J. Functional polymers and dendrimers: Reactivity, molecular architecture, and interfacial energy. Science 1994, 263, 1710-1715. [CrossRef] [PubMed]

8. Voit, B.I.; Lederer, A. Hyperbranched and highly branched polymer architectures-Synthetic strategies and major characterization aspects. Chem. Rev. 2009, 109, 5924-5973. [CrossRef] [PubMed]

9. Hedrick, J.L.; Magbitang, T.; Connor, E.F.; Glauser, T.; Volksen, W.; Hawker, C.J.; Lee, V.Y.; Miller, R.D. Application of complex macromolecular architectures for advanced microelectronic materials. Chem. Eur. J. 2002, 8, 3308-3319. [CrossRef]

10. Nyström, A.M.; Wooley, K.L. The importance of chemistry in creating well-defined nanoscopic embedded therapeutics: Devices capable of the dual functions of imaging and therapy. Acc. Chem. Res. 2011, 44, 969-978. [CrossRef] [PubMed]

11. Tomalia, D.A.; Baker, H.; Dewald, J.; Hall, M.; Kallos, G.; Martin, S.; Roeck, J.; Ryder, J.; Smith, P. A new class of polymers: Starburst-dendritic macromolecules. Polym. J. 1985, 17, 117-132. [CrossRef]

12. Bosman, A.W.; Janssen, H.M.; Meijer, E.W. About dendrimers: Structure, physical properties, and applications. Chem. Rev. 1999, 99, 1665-1688. [CrossRef] [PubMed]

13. Shi, Y.; Graff, R.W.; Cao, X.; Wang, X.; Gao, H. Chain-growth click polymerization of $\mathrm{AB}_{2}$ monomers for the formation of hyperbranched polymers with low polydispersities in a one-pot process. Angew. Chem. Int. Ed. 2015, 54, 7631-7635. [CrossRef] [PubMed]

14. Shi, Y.; Cao, X.; Gao, H. The use of azide-alkyne click chemistry in recent syntheses and applications of polytriazole-based nanostructured polymers. Nanoscale 2016, 8, 4864-4881. [CrossRef] [PubMed]

15. Emrick, T.; Chang, H.-T.; Frechet, J.M. An $\mathrm{A}_{2}+\mathrm{B}_{3}$ approach to hyperbranched aliphatic polyethers containing chain end epoxy substituents. Macromolecules 1999, 32, 6380-6382. [CrossRef]

16. Lin, Q.; Long, T.E. Polymerization of $\mathrm{A}_{2}$ with $\mathrm{B}_{3}$ monomers: $\mathrm{A}$ facile approach to hyperbranched poly(aryl ester)s. Macromolecules 2003, 36, 9809-9816. [CrossRef]

17. Wei, Q.; Pötzsch, R.; Liu, X.; Komber, H.; Kiriy, A.; Voit, B.; Will, P.-A.; Lenk, S.; Reineke, S. Hyperbranched polymers with high transparency and inherent high refractive index for application in organic light-emitting diodes. Adv. Funct. Mater. 2016, 26, 2545-2553. [CrossRef]

18. Liu, B.; Kazlauciunas, A.; Guthrie, J.T.; Perrier, S. One-pot hyperbranched polymer synthesis mediated by reversible addition fragmentation chain transfer (RAFT) polymerization. Macromolecules 2005, 38, 2131-2136. [CrossRef]

19. Gao, H.; Miasnikova, A.; Matyjaszewski, K. Effect of cross-linker reactivity on experimental gel points during atrcp of monomer and cross-linker. Macromolecules 2008, 41, 7843-7849. [CrossRef]

20. Gao, H.; Matyjaszewski, K. Synthesis of functional polymers with controlled architecture by CRP of monomers in the presence of cross-linkers: From stars to gels. Prog. Polym. Sci. 2009, 34, 317-350. [CrossRef]

21. Li, Y.; Armes, S.P. Synthesis of model primary amine-based branched copolymers by pseudo-living radical copolymerization and post-polymerization coupling of homopolymers. Macromolecules 2009, 42, 939-945. [CrossRef]

22. Han, H.; Tsarevsky, N.V. Employing exchange reactions involving hypervalent iodine compounds for the direct synthesis of azide-containing linear and branched polymers. Chem. Sci. 2014, 5, 4599-4609. [CrossRef]

23. Tang, H.; Tsarevsky, N.V. Lipoates as building blocks of sulfur-containing branched macromolecules. Polym. Chem. 2015, 6, 6936-6945. [CrossRef]

24. Liu, J.; Huang, W.; Zhou, Y.; Yan, D. Synthesis of hyperbranched polyphosphates by self-condensing ring-opening polymerization of heep without catalyst. Macromolecules 2009, 42, 4394-4399. [CrossRef]

25. Goodwin, A.; Baskaran, D. Inimer mediated synthesis of hyperbranched polyglycerol via self-condensing ring-opening polymerization. Macromolecules 2012, 45, 9657-9665. [CrossRef] 
26. Sunder, A.; Hanselmann, R.; Frey, H.; Muelhaupt, R. Controlled synthesis of hyperbranched polyglycerols by ring-opening multibranching polymerization. Macromolecules 1999, 32, 4240-4246. [CrossRef]

27. Fréchet, J.M.J.; Henmi, M.; Gitsov, I.; Aoshima, S.; Leduc, M.R.; Grubbs, R.B. Self-condensing vinyl polymerization: An approach to dendritic materials. Science 1995, 269, 1080-1083. [CrossRef] [PubMed]

28. Kato, M.; Kamigaito, M.; Sawamoto, M.; Higashimura, T. Polymerization of methyl methacrylate with the carbon tetrachloride/dichlorotris-(triphenylphosphine)ruthenium(II)/methylaluminum bis(2,6-di-tert-butylphenoxide) initiating system: Possibility of living radical polymerization. Macromolecules 1995, 28, 1721-1723. [CrossRef]

29. Wang, J.S.; Matyjaszewski, K. Controlled living radical polymerization-atom-transfer radical polymerization in the presence of transition-metal complexes. J. Am. Chem. Soc. 1995, 117, 5614-5615. [CrossRef]

30. Chiefari, J.; Chong, Y.K.; Ercole, F.; Krstina, J.; Jeffery, J.; Le, T.P.T.; Mayadunne, R.T.A.; Meijs, G.F.; Moad, C.L.; Moad, G.; et al. Living free-radical polymerization by reversible addition-Fragmentation chain transfer: The raft process. Macromolecules 1998, 31, 5559-5562. [CrossRef]

31. Matyjaszewski, K.; Xia, J. Atom transfer radical polymerization. Chem. Rev. 2001, 101, 2921-2990. [CrossRef] [PubMed]

32. Kamigaito, M.; Ando, T.; Sawamoto, M. Metal-catalyzed living radical polymerization. Chem. Rev. 2001, 101, 3689-3746. [CrossRef] [PubMed]

33. Hawker, C.J.; Bosman, A.W.; Harth, E. New polymer synthesis by nitroxide mediated living radical polymerizations. Chem. Rev. 2001, 101, 3661-3688. [CrossRef] [PubMed]

34. Moad, G.; Rizzardo, E.; Thang, S.H. Living radical polymerization by the raft process-A third update. Aust. J. Chem. 2012, 65, 985-1076. [CrossRef]

35. Szwarc, M. Living polymers. Nature 1956, 178, 1168-1169. [CrossRef]

36. Miyamoto, M.; Sawamoto, M.; Higashimura, T. Living polymerization of isobutyl vinyl ether with hydrogen iodide/iodine initiating system. Macromolecules 1984, 17, 265-268. [CrossRef]

37. Webster, O.W.; Hertler, W.R.; Sogah, D.Y.; Farnham, W.B.; RajanBabu, T.V. Group-transfer polymerization. 1. A new concept for addition polymerization with organosilicon initiators. J. Am. Chem. Soc. 1983, 105, 5706-5708. [CrossRef]

38. Hawker, C.J.; Frechet, J.M.J.; Grubbs, R.B.; Dao, J. Preparation of hyperbranched and star polymers by a "living", self-condensing free radical polymerization. J. Am. Chem. Soc. 1995, 117, 10763-10764. [CrossRef]

39. Li, C.; He, J.; Li, L.; Cao, J.; Yang, Y. Controlled radical polymerization of styrene in the presence of a polymerizable nitroxide compound. Macromolecules 1999, 32, 7012-7014. [CrossRef]

40. Tao, Y.; He, J.; Wang, Z.; Pan, J.; Jiang, H.; Chen, S.; Yang, Y. Synthesis of branched polystyrene and poly(styrene- $b$-4-methoxystyrene) by nitroxyl stable radical controlled polymerization. Macromolecules 2001, 34, 4742-4748. [CrossRef]

41. Niu, A.; Li, C.; Zhao, Y.; He, J.; Yang, Y.; Wu, C. Thermal decomposition kinetics and structure of novel polystyrene clusters with mtempo as a branching agent. Macromolecules 2001, 34, 460-464. [CrossRef]

42. Gaynor, S.G.; Edelman, S.; Matyjaszewski, K. Synthesis of branched and hyperbranched polystyrenes. Macromolecules 1996, 29, 1079-1081. [CrossRef]

43. Matyjaszewski, K.; Gaynor, S.G.; Kulfan, A.; Podwika, M. Preparation of hyperbranched polyacrylates by atom transfer radical polymerization. 1. Acrylic ab* monomers in "living" radical polymerizations. Macromolecules 1997, 30, 5192-5194. [CrossRef]

44. Cheng, G.; Simon, P.F.W.; Hartenstein, M.; Müller, A.H.E. Synthesis of hyperbranched poly(tert-butyl acrylate) by self-condensing atom transfer radical polymerization of a macroinimer. Macromol. Rapid Commun. 2000, 21, 846-852. [CrossRef]

45. Min, K.; Gao, H. New method to access hyperbranched polymers with uniform structure via one-pot polymerization of inimer in microemulsion. J. Am. Chem. Soc. 2012, 134, 15680-15683. [CrossRef] [PubMed]

46. Bibiao, J.; Yang, Y.; Xiang, J.; Rongqi, Z.; Jianjun, H.; Wenyun, W. Preparation of hyperbranched polymers by self-condensing vinyl radical polymerization. Eur. Polym. J. 2001, 37, 1975-1983. [CrossRef]

47. Graff, R.W.; Wang, X.; Gao, H. Exploring self-condensing vinyl polymerization of inimers in microemulsion to regulate the structures of hyperbranched polymers. Macromolecules 2015, 48, 2118-2126. [CrossRef]

48. Wang, X.; Graff, R.W.; Shi, Y.; Gao, H. One-pot synthesis of hyperstar polymers via sequential atrp of inimers and functional monomers in aqueous dispersed media. Polym. Chem. 2015, 6, 6739-6745. [CrossRef] 
49. Graff, R.W.; Shi, Y.; Wang, X.; Gao, H. Comparison of loading efficiency between hyperbranched polymers and cross-linked nanogels at various branching densities. Macromol. Rapid Commun. 2015, 36, 2076-2082. [CrossRef] [PubMed]

50. Hong, C.-Y.; Pan, C.-Y. Synthesis and characterization of hyperbranched polyacrylates in the presence of a tetrafunctional initiator with higher reactivity than monomer by self-condensing vinyl polymerization. Polymer 2001, 42, 9385-9391. [CrossRef]

51. Hong, C.-Y.; Pan, C.-Y.; Huang, Y.; Xu, Z.-D. Synthesis of hyperbranched polymethacrylates in the presence of a tetrafunctional initiator. Polymer 2001, 42, 6733-6740. [CrossRef]

52. Mori, H.; Böker, A.; Krausch, G.; Müller, A.H.E. Surface-grafted hyperbranched polymers via self-condensing atom transfer radical polymerization from silicon surfaces. Macromolecules 2001, 34, 6871-6882. [CrossRef]

53. Hong, C.Y.; Pan, C.Y. Preparation and characterization of hyperbranched polyacrylate copolymers by self-condensing vinyl copolymerization (SCVCP). Polym. Int. 2002, 51, 785-791. [CrossRef]

54. Mori, H.; Seng, D.C.; Lechner, H.; Zhang, M.; Müller, A.H.E. Synthesis and characterization of branched polyelectrolytes. 1. Preparation of hyperbranched poly(acrylic acid) via self-condensing atom transfer radical copolymerization. Macromolecules 2002, 35, 9270-9281. [CrossRef]

55. Yoo, S.H.; Lee, J.H.; Lee, J.-C.; Jho, J.Y. Synthesis of hyperbranched polyacrylates in emulsion by atom transfer radical polymerization. Macromolecules 2002, 35, 1146-1148. [CrossRef]

56. Jin, M.; Lu, R.; Bao, C.; Xu, T.; Zhao, Y. Synthesis and characterization of hyperbranched azobenzene-containing polymers via self-condensing atom transfer radical polymerization and copolymerization. Polymer 2004, 45, 1125-1131. [CrossRef]

57. Mori, H.; Walther, A.; André, X.; Lanzendörfer, M.G.; Müller, A.H.E. Synthesis of highly branched cationic polyelectrolytes via self-condensing atom transfer radical copolymerization with 2-(diethylamino)ethyl methacrylate. Macromolecules 2004, 37, 2054-2066. [CrossRef]

58. Cheng, C.; Wooley, K.L.; Khoshdel, E. Hyperbranched fluorocopolymers by atom transfer radical self-condensing vinyl copolymerization. J. Polym. Sci. A 2005, 43, 4754-4770. [CrossRef]

59. Hong, C.-Y.; You, Y.-Z.; Wu, D.; Liu, Y.; Pan, C.-Y. Multiwalled carbon nanotubes grafted with hyperbranched polymer shell via SCVP. Macromolecules 2005, 38, 2606-2611. [CrossRef]

60. Peeters, J.W.; Palmans, A.R.A.; Meijer, E.W.; Koning, C.E.; Heise, A. Chemoenzymatic synthesis of branched polymers. Macromol. Rapid Commun. 2005, 26, 684-689. [CrossRef]

61. Gong, F.; Tang, H.; Liu, C.; Jiang, B.; Ren, Q.; Yang, Y. Preparation of hyperbranched polymers through atrp of in situ formed AB* monomer. J. Appl. Polym. Sci. 2006, 101, 850-856. [CrossRef]

62. Muthukrishnan, S.; Erhard, D.P.; Mori, H.; Müller, A.H.E. Synthesis and characterization of surface-grafted hyperbranched glycomethacrylates. Macromolecules 2006, 39, 2743-2750. [CrossRef]

63. Gao, H.; Min, K.; Matyjaszewski, K. Gelation in atrp using structurally different branching reagents: Comparison of inimer, divinyl and trivinyl cross-linkers. Macromolecules 2009, 42, 8039-8043. [CrossRef]

64. Han, H.; Tsarevsky, N.V. Carboxylic acids as latent initiators of radical polymerization carried out in the presence of hypervalent iodine compounds: Synthesis of branched and transiently crosslinked polymers. Polym. Chem. 2012, 3, 1910-1917. [CrossRef]

65. Dong, B.-T.; Dong, Y.-Q.; Du, F.-S.; Li, Z.-C. Controlling polymer topology by atom transfer radical self-condensing vinyl polymerization of $p$-(2-bromoisobutyloylmethyl)styrene. Macromolecules 2010, 43, 8790-8798. [CrossRef]

66. Pugh, C.; Singh, A.; Samuel, R.; Bernal Ramos, K.M. Synthesis of hyperbranched polyacrylates by a chloroinimer approach. Macromolecules 2010, 43, 5222-5232. [CrossRef]

67. Huang, C.-F.; Kuo, S.-W.; Moravcikova, D.; Liao, J.-C.; Han, Y.-M.; Lee, T.-H.; Wang, P.-H.; Lee, R.-H.; Tsiang, R.C.-C.; Mosnacek, J. Effect of variations of $\mathrm{Cu}^{\mathrm{II}} \mathrm{X}_{2} / \mathrm{L}$ surface area of $\mathrm{Cu}^{0}$, solvent, and temperature on atom transfer radical polyaddition of 4-vinylbenzyl 2-bromo-2-isobutyrate inimers. RSC Adv. 2016, 6, 51816-51822. [CrossRef]

68. Chen, Z.-C.; Chiu, C.-L.; Huang, C.-F. Tuning the solubility of copper complex in atom transfer radical self-condensing vinyl polymerizations to control polymer topology via one-pot to the synthesis of hyperbranched core star polymers. Polymers 2014, 6, 2552-2572. [CrossRef]

69. Francis, R.; Ajayaghosh, A. Synthesis, characterization and radical copolymerization behaviour of S-methacryloyl O-methyl xanthate. Polymer 1995, 36, 1091-1096. [CrossRef] 
70. Francis, R.; Ajayaghosh, A. Minimization of homopolymer formation and control of dispersity in free radical induced graft polymerization using xanthate derived macro-photoinitiators. Macromolecules 2000, 33, 4699-4704. [CrossRef]

71. Ishizu, K.; Shibuya, T.; Kawauchi, S. Kinetics on formation of hyperbranched poly(ethyl methacrylate) via a controlled radical mechanism of photofunctional inimer. Macromolecules 2003, 36, 3505-3510. [CrossRef]

72. Wang, Z.; He, J.; Tao, Y.; Yang, L.; Jiang, H.; Yang, Y. Controlled chain branching by raft-based radical polymerization. Macromolecules 2003, 36, 7446-7452. [CrossRef]

73. Carter, S.; Hunt, B.; Rimmer, S. Highly branched poly( $N$-isopropylacrylamide)s with imidazole end groups prepared by radical polymerization in the presence of a styryl monomer containing a dithioester group. Macromolecules 2005, 38, 4595-4603. [CrossRef]

74. Carter, S.; Rimmer, S.; Rutkaite, R.; Swanson, L.; Fairclough, J.P.A.; Sturdy, A.; Webb, M. Highly branched poly(N-isopropylacrylamide) for use in protein purification. Biomacromolecules 2006, 7, 1124-1130. [CrossRef] [PubMed]

75. Peleshanko, S.; Gunawidjaja, R.; Petrash, S.; Tsukruk, V.V. Synthesis and interfacial behavior of amphiphilic hyperbranched polymers: Poly(ethylene oxide)-polystyrene hyperbranches. Macromolecules 2006, 39, 4756-4766. [CrossRef]

76. Hopkins, S.; Carter, S.; Swanson, L.; MacNeil, S.; Rimmer, S. Temperature-dependent phagocytosis of highly branched poly( $\mathrm{N}$-isopropyl acrylamide-co-1,2 propandiol-3-methacrylate)s prepared by raft polymerization. J. Mater. Chem. 2007, 17, 4022-4027. [CrossRef]

77. Vogt, A.P.; Gondi, S.R.; Sumerlin, B.S. Hyperbranched polymers via raft copolymerization of an acryloyl trithiocarbonate. Aust. J. Chem. 2007, 60, 396-399. [CrossRef]

78. Heidenreich, A.J.; Puskas, J.E. Synthesis of arborescent (dendritic) polystyrenes via controlled inimer-type reversible addition-fragmentation chain transfer polymerization. J. Polym. Sci. A 2008, 46, 7621-7627. [CrossRef]

79. Kwak, Y.; Nicolaÿ, R.; Matyjaszewski, K. Concurrent atrp/raft of styrene and methyl methacrylate with dithioesters catalyzed by copper(I) complexes. Macromolecules 2008, 41, 6602-6604. [CrossRef]

80. Vogt, A.P.; Sumerlin, B.S. Tuning the temperature response of branched poly(N-isopropylacrylamide) prepared by raft polymerization. Macromolecules 2008, 41, 7368-7373. [CrossRef]

81. Schmitt, J.; Blanchard, N.; Poly, J. Controlled synthesis of branched poly(vinyl acetate)s by xanthate-mediated raft self-condensing vinyl (co)polymerization. Polym. Chem. 2011, 2, 2231-2238. [CrossRef]

82. Zhang, C.; Zhou, Y.; Liu, Q.; Li, S.; Perrier, S.; Zhao, Y. Facile synthesis of hyperbranched and star-shaped polymers by RAFT polymerization based on a polymerizable trithiocarbonate. Macromolecules 2011, 44, 2034-2049. [CrossRef]

83. Zhou, X.; Zhu, J.; Xing, M.; Zhang, Z.; Cheng, Z.; Zhou, N.; Zhu, X. Synthesis and characters of hyperbranched poly(vinyl acetate) by raft polymerization. Eur. Polym. J. 2011, 47, 1912-1922. [CrossRef]

84. Han, J.; Li, S.; Tang, A.; Gao, C. Water-soluble and clickable segmented hyperbranched polymers for multifunctionalization and novel architecture construction. Macromolecules 2012, 45, 4966-4977. [CrossRef]

85. Wei, Z.; Hao, X.; Gan, Z.; Hughes, T.C. One-pot synthesis of hyperbranched glycopolymers by raft polymerization. J. Polym. Sci. A 2012, 50, 2378-2388. [CrossRef]

86. Zhang, M.; Liu, H.; Shao, W.; Ye, C.; Zhao, Y. Versatile synthesis of multiarm and miktoarm star polymers with a branched core by combination of menschutkin reaction and controlled polymerization. Macromolecules 2012, 45, 9312-9325. [CrossRef]

87. Li, S.; Han, J.; Gao, C. High-density and hetero-functional group engineering of segmented hyperbranched polymers via click chemistry. Polym. Chem. 2013, 4, 1774-1787. [CrossRef]

88. Zhang, M.; Liu, H.; Shao, W.; Miao, K.; Zhao, Y. Synthesis and properties of multicleavable amphiphilic dendritic comblike and toothbrushlike copolymers comprising alternating PEG and PCL grafts. Macromolecules 2013, 46, 1325-1336. [CrossRef]

89. Zhang, Y.; Teo, B.M.; Postma, A.; Ercole, F.; Ogaki, R.; Zhu, M.; Städler, B. Highly-branched poly(N-isopropylacrylamide) as a component in poly(dopamine) films. J. Phys. Chem. B 2013, 117, 10504-10512. [CrossRef] [PubMed]

90. Ghosh Roy, S.; De, P. Facile raft synthesis of side-chain amino acids containing ph-responsive hyperbranched and star architectures. Polym. Chem. 2014, 5, 6365-6378. [CrossRef] 
91. Sato, E.; Uehara, I.; Horibe, H.; Matsumoto, A. One-step synthesis of thermally curable hyperbranched polymers by addition-fragmentation chain transfer using divinyl monomers. Macromolecules 2014, 47, 937-943. [CrossRef]

92. Weng, Z.; Zheng, Y.; Tang, A.; Gao, C. Synthesis, dye encapsulation, and highly efficient colouring application of amphiphilic hyperbranched polymers. Aust. J. Chem. 2014, 67, 103-111. [CrossRef]

93. Zhuang, Y.; Su, Y.; Peng, Y.; Wang, D.; Deng, H.; Xi, X.; Zhu, X.; Lu, Y. Facile fabrication of redox-responsive thiol-containing drug delivery system via raft polymerization. Biomacromolecules 2014, 15, 1408-1418. [CrossRef] [PubMed]

94. Hu, X.; Liu, G.; Li, Y.; Wang, X.; Liu, S. Cell-penetrating hyperbranched polyprodrug amphiphiles for synergistic reductive milieu-triggered drug release and enhanced magnetic resonance signals. J. Am. Chem. Soc. 2015, 137, 362-368. [CrossRef] [PubMed]

95. Huang, J.; Lin, L.; Liang, H.; Lu, J. A facile synthesis of branched graft copolymers via combination of raft self-condensing vinyl polymerization and aldehyde-aminooxy reaction. Polym. Chem. 2015, 6, 4020-4029. [CrossRef]

96. Li, C.; Liu, H.; Tang, D.; Zhao, Y. Synthesis, postmodification and fluorescence properties of reduction-cleavable core-couplable miktoarm stars with a branched core. Polym. Chem. 2015, 6, 1474-1486. [CrossRef]

97. Rikkou-Kalourkoti, M.; Elladiou, M.; Patrickios, C.S. Synthesis and characterization of hyperbranched amphiphilic block copolymers prepared via self-condensing raft polymerization. J. Polym. Sci. A 2015, 53, 1310-1319. [CrossRef]

98. Wang, K.; Peng, H.; Thurecht, K.J.; Puttick, S.; Whittaker, A.K. Segmented highly branched copolymers: Rationally designed macromolecules for improved and tunable $19 \mathrm{f}$ mri. Biomacromolecules 2015, 16, 2827-2839. [CrossRef] [PubMed]

99. Alfurhood, J.A.; Sun, H.; Bachler, P.R.; Sumerlin, B.S. Hyperbranched poly(N-(2-hydroxypropyl) methacrylamide) via raft self-condensing vinyl polymerization. Polym. Chem. 2016, 7, 2099-2104. [CrossRef]

100. Haldar, U.; Roy, S.G.; De, P. Poss tethered hybrid “inimer" derived hyperbranched and star-shaped polymers via scvp-raft technique. Polymer 2016, 97, 113-121. [CrossRef]

101. Zheng, Y.; Tang, A.; Weng, Z.; Cai, S.; Jin, Y.; Gao, Z.; Gao, C. Amphiphilic hyperbranched polymers: Synthesis and host-guest supermolecular coloring application. Macromol. Chem. Phys. 2016, 217, 380-389. [CrossRef]

102. Zhuang, Y.; Deng, H.; Su, Y.; He, L.; Wang, R.; Tong, G.; He, D.; Zhu, X. Aptamer-functionalized and backbone redox-responsive hyperbranched polymer for targeted drug delivery in cancer therapy. Biomacromolecules 2016, 17, 2050-2062. [CrossRef] [PubMed]

103. Alfurhood, J.A.; Bachler, P.R.; Sumerlin, B.S. Hyperbranched polymers via raft self-condensing vinyl polymerization. Polym. Chem. 2016, 7, 3361-3369. [CrossRef]

104. Ishizu, K.; Mori, A. Novel synthesis of branched polystyrenes by quasi-living radical copolymerization using photofunctional inimer. Polym. Int. 2001, 50, 906-910. [CrossRef]

105. Ishizu, K.; Ohta, Y.; Kawauchi, S. Kinetics of hyperbranched polystyrenes by free radical polymerization of photofunctional inimer. Macromolecules 2002, 35, 3781-3784. [CrossRef]

106. Ishizu, K.; Shibuya, T.; Mori, A. Synthesis and characterization of hyperbranched poly(ethyl methacrylate) by quasi-living radical polymerization of photofunctional inimer. Polym. Int. 2002, 51, 424-428. [CrossRef]

107. Bektas, S.; Ciftci, M.; Yagci, Y. Hyperbranched polymers by visible light induced self-condensing vinyl polymerization and their modifications. Macromolecules 2013, 46, 6751-6757. [CrossRef]

108. Paulo, C.; Puskas, J.E. Synthesis of hyperbranched polyisobutylenes by inimer-type living polymerization. 1. Investigation of the effect of reaction conditions. Macromolecules 2001, 34, 734-739. [CrossRef]

109. Knauss, D.M.; Al-Muallem, H.A. Polystyrene with dendritic branching by convergent living anionic polymerization. Ii. Approach using vinylbenzyl chloride. J. Polym. Sci. A 2000, 38, 4289-4298. [CrossRef]

110. Knauss, D.M.; Al-Muallem, H.A.; Huang, T.; Wu, D.T. Polystyrene with dendritic branching by convergent living anionic polymerization. Macromolecules 2000, 33, 3557-3568. [CrossRef]

111. Sun, W.; He, J.; Wang, X.; Zhang, C.; Zhang, H.; Yang, Y. Synthesis of dendritic polystyrenes from an anionic inimer. Macromolecules 2009, 42, 7309-7317. [CrossRef]

112. Jia, Z.; Yan, D. Hyperbranched polymers generated from oxyanionic vinyl polymerization of commercially available methacrylate inimers. J. Polym. Sci. A 2005, 43, 3502-3509. [CrossRef] 
113. Baskaran, D. Hyperbranched polymers from divinylbenzene and 1,3-diisopropenylbenzene through anionic self-condensing vinyl polymerization. Polymer 2003, 44, 2213-2220. [CrossRef]

114. Baskaran, D. Synthesis of hyperbranched polymers by anionic self-condensing vinyl polymerization. Macromol. Chem. Phys. 2001, 202, 1569-1575. [CrossRef]

115. Xie, C.; Ju, Z.; Zhang, C.; Yang, Y.; He, J. Dendritic block and dendritic brush copolymers through anionic macroinimer approach. Macromolecules 2013, 46, 1437-1446. [CrossRef]

116. Yang, H.; Bai, T.; Xue, X.; Huang, W.; Chen, J.; Qian, X.; Zhang, G.; Jiang, B. A simple route to vinyl-functionalized hyperbranched polymers: Self-condensing anionic copolymerization of allyl methacrylate and hydroxyethyl methacrylate. Polymer 2015, 72, 63-68. [CrossRef]

117. Simon, P.F.W.; Radke, W.; Müller, A.H.E. Hyperbranched methacrylates by self-condensing group transfer polymerization. Macromol. Rapid Commun. 1997, 18, 865-873. [CrossRef]

118. Simon, P.F.W.; Mueller, A.H.E. Kinetic investigation of self-condensing group transfer polymerization. Macromolecules 2004, 37, 7548-7558. [CrossRef]

119. Lu, P.; Paulasaari, J.K.; Weber, W.P. Hyperbranched poly(4-acetylstyrene) by ruthenium-catalyzed step-growth polymerization of 4-acetylstyrene. Macromolecules 1996, 29, 8583-8586. [CrossRef]

120. Georges, M.K.; Veregin, R.P.N.; Kazmaier, P.M.; Hamer, G.K. Narrow molecular weight resins by a free-radical polymerization process. Macromolecules 1993, 26, 2987-2988. [CrossRef]

121. Grubbs, R.B. Nitroxide-mediated radical polymerization: Limitations and versatility. Polym. Rev. 2011, 51, 104-137. [CrossRef]

122. Matyjaszewski, K.; Gaynor, S.G. Preparation of hyperbranched polyacrylates by atom transfer radical polymerization. 3. Effect of reaction conditions on the self-condensing vinyl polymerization of 2-((2-bromopropionyl)oxy)ethyl acrylate. Macromolecules 1997, 30, 7042-7049. [CrossRef]

123. Matyjaszewski, K.; Pyun, J.; Gaynor, S.G. Preparation of hyperbranched polyacrylates by atom transfer radical polymerization, 4. The use of zero-valent copper. Macromol. Rapid Commun. 1998, 19, 665-670. [CrossRef]

124. Yoo, S.H.; Yoon, T.H.; Jho, J.Y. Controlling the degree of branching in atom-transfer radical polymerization of hyperbranched polyacrylates. Macromol. Rapid Commun. 2001, 22, 1319-1324. [CrossRef]

125. Bibiao, J.; Yang, Y.; Jian, D.; Shiyang, F.; Rongqi, Z.; Jianjun, H.; Wenyun, W. Preparation of hyperbranched polymers by atom transfer radical polymerization. J. Appl. Polym. Sci. 2002, 83, 2114-2123. [CrossRef]

126. Rikkou-Kalourkoti, M.; Matyjaszewski, K.; Patrickios, C.S. Synthesis, characterization and thermolysis of hyperbranched homo- and amphiphilic co-polymers prepared using an inimer bearing a thermolyzable acylal group. Macromolecules 2012, 45, 1313-1320. [CrossRef]

127. Gao, C.; Zheng, X. Facile synthesis and self-assembly of multihetero-arm hyperbranched polymer brushes. Soft Matter 2009, 5, 4788-4796. [CrossRef]

128. Barner, L.; Davis, T.P.; Stenzel, M.H.; Barner-Kowollik, C. Complex macromolecular architectures by reversible addition fragmentation chain transfer chemistry: Theory and practice. Macromol. Rapid Commun. 2007, 28, 539-559. [CrossRef]

129. Ishizu, K.; Mori, A. Synthesis of hyperbranched polymers by self-addition free radical vinyl polymerization of photo functional styrene. Macromol. Rapid Commun. 2000, 21, 665-668. [CrossRef]

130. Akabori, K.-I.; Atarashi, H.; Ozawa, M.; Kondo, T.; Nagamura, T.; Tanaka, K. Glass transition behavior of hyper-branched polystyrenes. Polymer 2009, 50, 4868-4875. [CrossRef]

131. Wang, X.; Shi, Y.; Graff, R.W.; Cao, X.; Gao, H. Synthesis of hyperbranched polymers with high molecular weight in the homopolymerization of polymerizable trithiocarbonate transfer agent without thermal initiator. Macromolecules 2016, 49, 6471-6479. [CrossRef]

132. Jiang, Q.; Huang, W.; Yang, H.; Xue, X.; Jiang, B.; Zhang, D.; Fang, J.; Chen, J.; Yang, Y.; Zhai, G.; et al. Radical emulsion polymerization with chain transfer monomer: An approach to branched vinyl polymers with high molecular weight and relatively narrow polydispersity. Polym. Chem. 2014, 5, 1863-1873. [CrossRef]

133. Hanselmann, R.; Hölter, D.; Frey, H. Hyperbranched polymers prepared via the core-dilution/slow addition technique: Computer simulation of molecular weight distribution and degree of branching. Macromolecules 1998, 31, 3790-3801. [CrossRef]

134. Radke, W.; Litvinenko, G.; Müller, A.H.E. Effect of core-forming molecules on molecular weight distribution and degree of branching in the synthesis of hyperbranched polymers. Macromolecules 1998, 31, 239-248. [CrossRef] 
135. Bharathi, P.; Moore, J.S. Solid-supported hyperbranched polymerization: Evidence for self-limited growth. J. Am. Chem. Soc. 1997, 119, 3391-3392. [CrossRef]

136. Misra, S.K.; Wang, X.; Srivastava, I.; Imgruet, M.K.; Graff, R.W.; Ohoka, A.; Kampert, T.L.; Gao, H.; Pan, D. Combinatorial therapy for triple negative breast cancer using hyperstar polymer-based nanoparticles. Chem. Commun. 2015, 51, 16710-16713. [CrossRef] [PubMed]

137. Wei, X.; Luo, Q.; Sun, L.; Li, X.; Zhu, H.; Guan, P.; Wu, M.; Luo, K.; Gong, Q. Enzyme- and pH-sensitive branched polymer-doxorubicin conjugate-based nanoscale drug delivery system for cancer therapy. ACS Appl. Mater. Interfaces 2016, 8, 11765-11778. [CrossRef] [PubMed]

138. Li, Y.; Laurent, S.; Esser, L.; Elst, L.V.; Muller, R.N.; Lowe, A.B.; Boyer, C.; Davis, T.P. The precise molecular location of gadolinium atoms has a significant influence on the efficacy of nanoparticulate mri positive contrast agents. Polym. Chem. 2014, 5, 2592-2601. [CrossRef]

139. Jackson, A.W.; Chandrasekharan, P.; Ramasamy, B.; Goggi, J.; Chuang, K.-H.; He, T.; Robins, E.G. Octreotide functionalized nano-contrast agent for targeted magnetic resonance imaging. Biomacromolecules 2016, 17, 3902-3910. [CrossRef] [PubMed]

140. Hu, D.; Jin, S.; Shi, Y.; Wang, X.; Graff, R.W.; Liu, W.; Zhu, M.; Gao, H. Preparation of hyperstar polymers with encapsulated $\mathrm{Au}$ 25(SR)18 clusters as recyclable catalysts for nitrophenol reduction. Nanoscale 2017, 9, 3629-3636. [CrossRef] [PubMed]

141. Pan, X.; Tasdelen, M.A.; Laun, J.; Junkers, T.; Yagci, Y.; Matyjaszewski, K. Photomediated controlled radical polymerization. Prog. Polym. Sci. 2016, 62, 73-125. [CrossRef]

142. Chen, M.; Zhong, M.; Johnson, J.A. Light-controlled radical polymerization: Mechanisms, methods, and applications. Chem. Rev. 2016, 116, 10167-10211. [CrossRef] [PubMed]

143. Matyjaszewski, K.; Jakubowski, W.; Min, K.; Tang, W.; Huang, J.; Braunecker, W.A.; Tsarevsky, N.V. Diminishing catalyst concentration in atom transfer radical polymerization with reducing agents. Proc. Natl. Acad. Sci. USA 2006, 103, 15309-15314. [CrossRef] [PubMed]

144. Chmielarz, P.; Fantin, M.; Park, S.; Isse, A.A.; Gennaro, A.; Magenau, A.J.D.; Sobkowiak, A.; Matyjaszewski, K. Electrochemically mediated atom transfer radical polymerization (eATRP). Prog. Polym. Sci. 2017, 69, 47-78. [CrossRef]

145. Treat, N.J.; Sprafke, H.; Kramer, J.W.; Clark, P.G.; Barton, B.E.; Read de Alaniz, J.; Fors, B.P.; Hawker, C.J. Metal-free atom transfer radical polymerization. J. Am. Chem. Soc. 2014, 136, 16096-16101. [CrossRef] [PubMed]

146. Matyjaszewski, K. Atom transfer radical polymerization (ATRP): Current status and future perspectives. Macromolecules 2012, 45, 4015-4039. [CrossRef] 